\title{
Identification of Optimum Route Alignment in Landslide Areas: A Case Study from Sri Lanka
}

\author{
Nayana Padmani WAK* and Sudath RA
}

Planning Division, Road Development Authority (RDA), Koswatta, Battaramulla, Sri Lanka

\begin{abstract}
In Sri Lanka road network, especially in hilly terrain is affected by landslide in every rainy season. Therefore, the maintenance cost of the Road Development Authority is increasing and roads have to be closed for traffic due to landslides. Hence developing a methodology to identify an optimum route alignment in landslide areas is essential in the planning of roads. To identify the optimum route alignment for Beragala-Koslanda landslide area, geo-informatics approach was used considering engineering factors simultaneously in the present study. 1:10,000 scale topographic map, 30 m resolution downloaded USGS DEM, 1: 100,000 geology map and 1: 50,000 landslide hazard zone map were used as basic input data for the analysis. Using the basic input data, seven layers (Landslide hazard zone, Land use and management, Slope, Drainage density, Populated area, Sensitivity area and Lithology) were extracted and further they were weighted and ranked using Spatial Multi Criteria Analysis (SMCA) according to the values given by experts in the field of geology and highway engineering. The least cost path for the area was identified by using the least cost path algorithm in Arc GIS 10.2. Field verification was conducted with the participation of civil engineers and GPS (Global Positioning System) were used to go through the identified path. Finally, $15.414 \mathrm{~km}$ length alternative route was identified from Beragala to Koslanda landslide area. The final result obtained in this study supports other researches in the application of GIS and SMCA in complex planning. Possibilities of applying GIS and SMCA in identifying the route alignment avoiding landslide risk areas, was proved in this study.
\end{abstract}

Keywords: GIS; Remote sensing; Spatial multi criteria analysis; Global positioning system

\section{Introduction}

\section{Research problem}

Although Sri Lanka has a well-connected road network that contributes to the mobility, most of the roads in hilly area are affected by landslide in every rainy season. Therefore, the maintenance cost of the Road Development Authority is increasing and roads have to be closed for traffic due to landslides. The situation is aggravated by the geological structure of the area and due to human activities. Therefore, there is a great need for effective route planning, which is capable of avoiding landslide prone areas, incorporating engineering design and various geological factors in terms of slope stability and safety.

Over the last decade, many studies relevant to landslides susceptibility assessment can be found in the field of GIS (Geographical Information System) and RS (Remote Sensing) [1]. However, studies related to road construction combining with GIS and RS are limited. This situation is same for worldwide studies. Application of GIS and RS in identification of most suitable route alignment in landslide vulnerable area has not been studied in Sri Lanka.

\section{Objectives of the study}

The objective of this study is to develop a methodology using GIS and Remote Sensing for the identification of optimum route alignment in landslide prone areas.

The approach in the development of the methodology is as follows:

1. Identify the factors for road construction.

2. Identify a least cost path for the Landslide area.

3. Identify an optimum route alignment in Landslide area.

This method was applied to Beragala - Koslanda road section on Colombo - Ratnapura - Wellawaya - Batticaloa (A004) road.

\section{Justification of the study}

Common mode of transport in hilly areas is the road transport. The situation is same for other parts of the country as well. A well spread road network especially National Road Network contribute to that by providing accessibility to most parts of the country (Planning Division, RDA). Central part of the country, being a hilly terrain, the maintenance cost of roads is high especially due to frequent occurrence of landslides. Initially, during planning stage of a route alignment landslide prone areas are avoided. However, due to the change in climatic conditions and human activities, areas prone to landslides are increasing. If the identification of routes is carried out by avoiding potential landslide areas, the maintenance cost spends on roads in every rainy season can be avoided or reduced. In the past, this was not possible due to lack of information and technology. With development of GIS and RS technologies, data gathering and analysis is possible to avoid more sensitive areas and select most cost-effective road projects.

Cutting and filling, one of the main activities in construction of the roads, especially in mountainous areas can directly trigger landslides. Therefore, it is needed to identify the most suitable corridor for road construction considering landslide distribution, slope of the area, land use, drainage order etc. If the map of landslide prone area is available, the route selection can be done avoiding landslides.

*Corresponding author: Nayana Padmani, Planning Division, Road Developmen Authority (RDA), Koswatta, Battaramulla, Sri Lanka, Tel: +94714409988; E-mail: nayanarda@gmail.com

Received July 19, 2017; Accepted July 26, 2017; Published July 28, 2017

Citation: Nayana Padmani WAK, Sudath RA (2017) Identification of Optimum Route Alignment in Landslide Areas: A Case Study from Sri Lanka. J Remote Sensing \& GIS 6: 206. doi: 10.4172/2469-4134.1000206

Copyright: (c) 2017 Nayana Padmani WAK, et al. This is an open-access article distributed under the terms of the Creative Commons Attribution License, which permits unrestricted use, distribution, and reproduction in any medium, provided the original author and source are credited. 
Citation: Nayana Padmani WAK, Sudath RA (2017) Identification of Optimum Route Alignment in Landslide Areas: A Case Study from Sri Lanka. J Remote Sensing \& GIS 6: 206. doi: 10.4172/2469-4134.1000206

Page 2 of 7

\section{Study Area, Data and Methodology}

\section{Study area}

The study area is belonged to the intermediate zone that receives 1000-1500 mm of mean annual rainfall and also located mainly within the Walawe river basin. Altitude has a great impact on air temperature in Sri Lanka than latitude. Maximum elevation of the study area is 1578 m. Mean annual temperature of the study area is in between $20^{\circ} \mathrm{C}$ and $22.5^{\circ} \mathrm{C}[2]$

The study location is the Beragala - Koslanda area in Badulla District, Uva Province of Sri Lanka, which is located between $6^{\circ} 46^{\prime} 28^{\prime \prime} \mathrm{N}$ to $6^{\circ} 41^{\prime} 01^{\prime \prime} \mathrm{N}$ latitude and between $80^{\circ} 54^{\prime} 20^{\prime \prime} \mathrm{E}$ to $81^{\circ} 02^{\prime} 42^{\prime \prime} \mathrm{E}$ longitude. Figure 1 depicts the location of the study area.

\section{Data used in the study}

This study is mainly based on secondary data. Table 1 describes the data used in this study. Topographic map of the study area was used to extract the land use pattern, road network, sensitivity area, water bodies and building layer of the area. A digital layer of the map of landslide hazard zone, prepared by National Building Research Organization (NBRO) was used as a one of the main data set of this study. Downloaded USGS Digital Elevation Model (DEM) with the 30 $\mathrm{m}$ resolution was also used to prepare the slope map and the drainage pattern of the study area.

\section{Methodology}

Identifying significant factors for road construction: The first step of the study is to identify the factor affecting road construction (Road alignment selection) in a terrain similar to the area selected. For this purpose, journals, books, manuals and World Wide Web were referred. And also discussions were held with senior engineers who are having experience in selection and design of roads. Landslide distribution, Land use and management, Slope, Drainage order, Populated area, Sensitivity area, Geology and Soil are the factors identified.

Weighting and ranking the factors: To fulfil the objective 'Identify the factors for road construction' of the study, the factors which used to identify the optimum route alignment, have been weighted and ranked using multi criteria analysis. Spatial multi criteria analysis was conducted according to the pair wise comparison matrix. Judgment of five experts was used in this pair wise comparison. Considering the cost, these criteria have been weighted and ranked by expertise. According to their values, pairwise matrix was created.

Cost surface and cost distance raster: After determination of the comparative weight of parameters, the derived weights from pairwise matrix in Spatial Multi Criteria Analysis (SMCA), inserting the particular value to the map layers, weighted thematic maps for each and every factor was prepared. The thematic cost map is defined as a raster map, where the value at each pixel gives the estimated relative

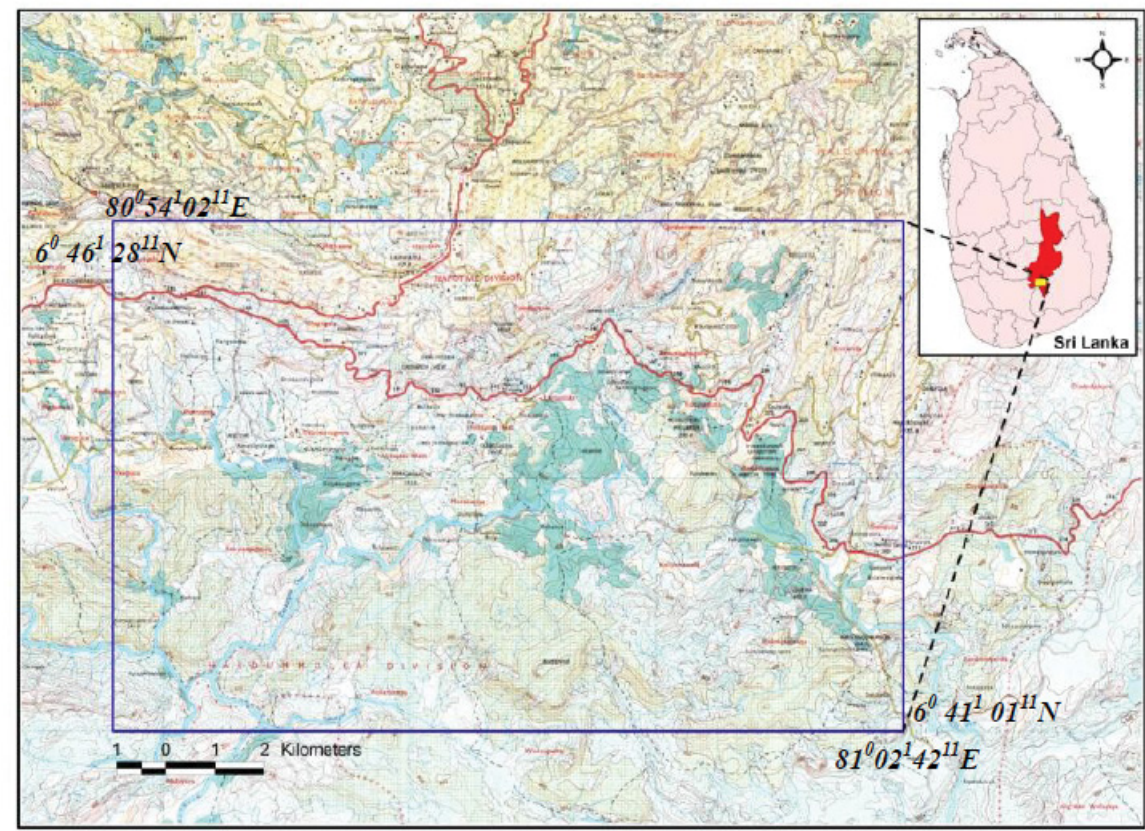

Figure 1: Location Map of the Study Area

\begin{tabular}{|c|c|c|c|c|}
\hline \multicolumn{2}{|c|}{ Data Format } & Types of Data & Source of Data & Resolution of Data \\
\hline $\begin{array}{l}\text { Secondary } \\
\text { Data }\end{array}$ & Vector Data & Topographic Map & Survey Department of Sri Lanka & $1: 10,000$ \\
\hline & & Landslide Data & National Building Research Organization (NBRO) & $1: 50,000$ \\
\hline & & Lithology Map & $\begin{array}{l}\text { Geological Survey Mines Bureau (GSMB), Sri } \\
\text { Lanka }\end{array}$ & $1: 100,000$ \\
\hline & Raster Data & Digital Elevation Model (DEM) & USGS DEM & $30 \mathrm{~m}$ \\
\hline & Other Data & $\begin{array}{l}\text { Detail about the roads affected by } \\
\text { landslides }\end{array}$ & Road Development Authority (RDA), Sri Lanka & - \\
\hline Primary Data & & GPS and Field Surveying Data & Collected & - \\
\hline
\end{tabular}

Table 1: Data Used for the Study. 
cost of route development and maintenances through the pixel. It is dependent upon a number of factors and the most important of these being landslide hazard zone, slope, drainage order, land use, populated area (building density), lithology and sensitivity area.

According to above method, thematic cost maps for all seven factors were prepared. As per the weighted values given in the pairwise matrix and ranked values given by expertise, all those cost maps were produced. By integrating these weighted raster, the final thematic cost map has been prepared.

GIS can be introduced as a very useful tool for finding the best route from one location to another in both vector-based and rasterbased methods. Network analysis, which relies on a route system, is one general method in vector-based method. Cost distance/cost path, which is a raster-based method, can be mentioned as second method as well [3]. Because this study is based on raster-based format, cost distance/ cost path has been selected. In the cost distance analysis in ArcGIS, the value of each cell represents the cost per unit distance of cross that cell. The cost is based on several variables, used for the analysis.

The specification of cost distance, the least accumulative cost distance is calculated for each cell to nearest source over a cost surface. The cost to travel between one node to the next is depending on the spatial orientation of the nodes. How the cells are connected also impacts the travel cost. This is identified as 'node travel cost' [4]. Based on above cost raster surface map the least cost path was obtained.

\section{Results and Discussion}

\section{Weighting and ranking the factors}

Spatial multi criteria analysis: Considering all factors, according to the weighted values given by the expertise, the finalized pair wise matrix was prepared and it is shown in the Table 2. The landslide hazard zone has the highest cost weight of 0.235 (23\%) showing that it has the highest friction and as such is very expensive to build a road across the landslide hazard zone. If the road is going through the landslide area, it should be spent huge amount of money to avoid risk of landslides. All the experts have given the highest weighted value for the landslide factor due to difficulties of maintenance after landslide effects.
Schools, hospitals, religious places are considered as the sensitivity area which are in the study area. When select the alignment for road construction, these areas should be avoided since there is no way to replace as well When designing a route alignment especially in hilly terrain, slope of the area has to be considered. According to the slope of the area cutting and filling areas are decided since the necessary gradient is to be kept. If several cuttings and filling areas are crossed by the route, the construction cost of the road is very high. If the path can be selected through the flat area, this cost can be reduced.

Due to resettlement problems, the areas where the buildings are distributed have to be avoided as much as possible when planning a route alignment. According to the building density of the area, the alignment is selected through the lowest density area. Then the costs which spend for resettlement can be minimized.

Drainage order in the study area is distributed from order one to order seven. Order 1 is no required to construct a bridge and order 7 is required to construct a large bridge when the road is going over the streams. And also, if the road has to pass so many streams, the requirement of constructing bridges is increased. Finally, construction and maintain cost of the road is very high. Therefore, it is clear that the consideration of drainage order is very essential when selecting a route alignment.

Generally, the land value is depending on the type of land use. Therefore, when identify the route, land use of the area should be considered. The land acquisition cost of the abandoned area is less than the cultivated or built-up area. Therefore, before designing an alignment of the road, it is important to consider the land use pattern of the area. The other considerable factor is lithology of the area. In this study, it has taken the lowest weighted value (0.096) in the SMCA. Although it has taken a lowest value compared with other factors, it should be considered when selecting routes.

\section{Preparation of thematic cost map}

As per the pair wise matrix, the following table (Table 3 ) is shown their weighted and ranked values as well as cost values of the cell.

Using those cost values in Table 3, the thematic cost maps for

\begin{tabular}{|c|c|c|c|c|c|c|c|c|c|c|}
\hline & \multicolumn{2}{|c|}{ LS } & SEN & POP & \multicolumn{2}{|l|}{ SLOP } & \multicolumn{2}{|l|}{ DRN } & LUSE & LITHO \\
\hline LS & \multicolumn{2}{|c|}{1.000} & 1.000 & 1.680 & \multicolumn{2}{|l|}{1.960} & \multicolumn{2}{|l|}{2.260} & 2.400 & 4.400 \\
\hline SEN & \multicolumn{2}{|c|}{0.980} & 1.000 & 1.040 & \multicolumn{2}{|l|}{1.100} & \multicolumn{2}{|l|}{1.200} & 1.400 & 2.000 \\
\hline POP & \multicolumn{2}{|c|}{0.940} & 0.680 & 1.000 & \multicolumn{2}{|l|}{1.060} & \multicolumn{2}{|l|}{1.140} & 1.300 & 2.360 \\
\hline SLOP & \multicolumn{2}{|c|}{0.920} & 0.490 & 0.970 & \multicolumn{2}{|l|}{1.000} & \multicolumn{2}{|l|}{1.320} & 1.960 & 2.360 \\
\hline DRN & \multicolumn{2}{|c|}{0.880} & 0.470 & 0.770 & \multicolumn{2}{|l|}{0.960} & \multicolumn{2}{|l|}{1.000} & 1.900 & 2.000 \\
\hline LUSE & \multicolumn{2}{|c|}{0.860} & 0.290 & 0.850 & \multicolumn{2}{|l|}{0.900} & \multicolumn{2}{|l|}{0.940} & 1.000 & 1.320 \\
\hline LITHO & \multicolumn{2}{|c|}{0.820} & 0.310 & 0.840 & \multicolumn{2}{|l|}{0.860} & \multicolumn{2}{|l|}{0.860} & 0.900 & 1.000 \\
\hline Total & \multicolumn{2}{|c|}{6.400} & 4.240 & 7.150 & 7.840 & & \multicolumn{2}{|l|}{8.720} & 10.860 & 15.440 \\
\hline & LS & SEN & POP & SLOP & DRN & LUSE & & LITHO & Total & Weighted Value \\
\hline LS & 0.156 & 0.236 & 0.235 & 0.250 & 0.259 & 0.221 & & 0.285 & 1.642 & 0.235 \\
\hline SEN & 0.153 & 0.236 & 0.145 & 0.140 & 0.138 & 0.129 & & 0.130 & 1.071 & 0.153 \\
\hline POP & 0.147 & 0.160 & 0.140 & 0.135 & 0.131 & 0.120 & & 0.153 & 0.986 & 0.141 \\
\hline SLOP & 0.144 & 0.116 & 0.136 & 0.128 & 0.151 & 0.180 & & 0.153 & 1.007 & 0.144 \\
\hline DRN & 0.138 & 0.111 & 0.108 & 0.122 & 0.115 & 0.175 & & 0.130 & 0.898 & 0.128 \\
\hline LUSE & 0.134 & 0.068 & 0.119 & 0.115 & 0.108 & 0.092 & & 0.085 & 0.722 & 0.103 \\
\hline LITHO & 0.128 & 0.073 & 0.117 & 0.110 & 0.099 & 0.083 & & 0.065 & 0.675 & 0.096 \\
\hline & & & & & & & & & & 1.000 \\
\hline
\end{tabular}

LS- Landslide Hazard Zone, SEN- Sensitivity Area, POP- Populated area (Building Density), SLOP- Slope Classes, DRN- Drainage Density, LUSE- Land use and Management, LITHO- Lithology. 
Citation: Nayana Padmani WAK, Sudath RA (2017) Identification of Optimum Route Alignment in Landslide Areas: A Case Study from Sri Lanka. J Remote Sensing \& GIS 6: 206. doi: 10.4172/2469-4134.1000206

Page 4 of 7

all factors were prepared. By integrating above all cost raster maps together, the map of cost raster surface has been created. It can be called as the overall suitability map because it shows the most suitable area for road construction displaying minimum values of the cells. Figure 2 shows the map of cost raster and it is shown that the values of cells are distributed from 0.985 to 7.241 . While 0.985 is taken the most suitable area for road construction, the value 7.241 is taken as unsuitable area for road construction. Again, it is clear that the existing road section from Beragala to Koslanda goes through the high cost area.

Finding a least cost path: By combining least cost cells of the cost surface map using Spatial Analysis tool in Arc GIS, the least cost path was built (Figure 2). According to the map it is clear that cost values of cells are distributed from low value (0.985) to a high value (7.241). Since the main objective of this study is to find an optimum alternative route for Beragala - Koslanda road section. It should be a least cost path as well considering all factors. This path was overlaid on the three dimensions (3D) terrain of the area. Some certain level it helps us to verify the suitability or unsuitability of the created path. Figure 3 shows how the path is laid on the terrain.

According to the Figure 3, elevation of the study area varies from $130 \mathrm{~m}$ to $1760 \mathrm{~m}$. With this variations road has to keep its geometric alignments also. According to the Figure 3, the identified trace traverses through a much better terrain compared to the existing A004 road section from Beragala to Koslanda. However, the starting section of the identified path has gone through steep slope, since the given source point is in the very steep slope area. Expertise advised to use starting point as much as far away from Beragala Junction to avoid this problem, because Beragala junction is in the very steep slope area. But due to lack of necessary data for the wide area this had to be done. Existing A004 road is crossing streams everywhere and it causes damage the road and increase the maintaining cost of the road. But new road is crossing less streams comparing with existing road.

\section{Geometric design of the road}

Horizontal alignment: In general, the horizontal alignment of a road is based on the radius of the curvatures. The trace identified by the model is the least cost path though it has more horizontal curves. This is mainly due to the grid base data set used for the analysis. The initial trace derived through the model was reduced the radius to an acceptable level suit for the terrain using ArcGIS 10.0 version.

Since this road section belongs to the ' $A$ ' class national road network, the proposed section should satisfy following requirements as per the Geometric Design Standards of RDA [5], design speed is 70 $\mathrm{km} / \mathrm{ph}$ and the radius varies from 155 to 225 and also super elevation should be $2.5 \%$. With the radius value 225 , the path had to be smoothed. Figure 4 shows that the smooth line is overlaid on the grid base path.

Then it is clear that this least cost path has become more accurate route with the required horizontal alignments. And also, new alignment keeps its $30 \mathrm{~m}$ limits while making the smoothest route. Therefore, this route can be verified as most accurate alignment that keeping a maximum and best radius for the area.

\begin{tabular}{|c|c|c|c|c|c|}
\hline Factor & Weighted Value & Factor classes & Linguistic Rating & Rank Value & Cost Value of the cell \\
\hline \multirow{4}{*}{ Landslide Hazard Zone } & \multirow{4}{*}{0.235} & Landslides most likely to occur & Very High & 9 & 2.115 \\
\hline & & Landslides are to be expected & Medium & 7 & 1.645 \\
\hline & & Modest level of hazard exists & Low & 5 & 1.175 \\
\hline & & Landslides not likely to occur & Very Low & 1 & 0.235 \\
\hline Sensitivity Area & 0.153 & Religious places, Schools and Hospitals & Very High & 9 & 1.375 \\
\hline \multirow{4}{*}{ Slope } & \multirow{4}{*}{0.144} & Mountain Terrain (Degrees >25) & Very High & 8 & 1.152 \\
\hline & & Rolling Terrain (Degrees 11-25) & Medium & 5 & 0.720 \\
\hline & & Flat Terrain (Degrees 0-10) & Low & 1 & 0.144 \\
\hline & & Mountain Terrain (Degrees >25) & Very High & 8 & 1.152 \\
\hline \multirow{4}{*}{$\begin{array}{c}\text { Populated Area (Building } \\
\text { Density) }\end{array}$} & \multirow{4}{*}{0.141} & $3415-7895$ & Very High & 9 & 1.269 \\
\hline & & $1449-3414$ & Medium & 7 & 0.987 \\
\hline & & $250-1448$ & Low & 4 & 0.564 \\
\hline & & 0 & Very Low & 1 & 0.141 \\
\hline \multirow{4}{*}{ Drainage Order } & \multirow{4}{*}{0.128} & Order 6-7 & High & 6 & 0.768 \\
\hline & & Order 4-5 & Medium & 5 & 0.640 \\
\hline & & Order 2-3 & Medium & 4 & 0.512 \\
\hline & & Order 1 & Low & 2 & 0.256 \\
\hline \multirow{5}{*}{$\begin{array}{l}\text { Land Use and } \\
\text { Management }\end{array}$} & \multirow{5}{*}{0.103} & Forest-unclassified & Very High & 8 & 0.824 \\
\hline & & Homestead/Garden, Paddy, Rubber, Sugarcane, Tea & Medium & 6 & 0.618 \\
\hline & & Hydro & High & 7 & 0.721 \\
\hline & & Scrub land, Other cultivation & Low & 4 & 0.412 \\
\hline & & Rock & Medium & 6 & 0.618 \\
\hline \multirow{4}{*}{ Lithology } & \multirow{4}{*}{0.096} & Calc-gneisses and/ or granulites,Marble & High & 6 & 0.576 \\
\hline & & $\begin{array}{l}\text { Garnetiferousquartzofeldspathic gneiss, Impure } \\
\text { quartzites and quartz schists, Quartzite's, } \\
\text { Quartzofeldspathic gneiss }\end{array}$ & Medium & 5 & 0.480 \\
\hline & & $\begin{array}{l}\text { Hornblende-biotitemigmatite, Undifferentiated } \\
\text { charnockiticbiotite gneisses, Very coarse grained to } \\
\text { pegmatitic }\end{array}$ & High & 6 & 0.576 \\
\hline & & $\begin{array}{l}\text { Garnet-silimanite-biotite gneiss graphite, Garnet- } \\
\text { silimanite-biotite gneiss graphite with up to } 30 \% \text { large } \\
\qquad\left(1-3^{\star}\right)\end{array}$ & High & 7 & 0.672 \\
\hline
\end{tabular}

Table 3: Weighted and Ranked Value Given for Landslide Hazard zone 
Citation: Nayana Padmani WAK, Sudath RA (2017) Identification of Optimum Route Alignment in Landslide Areas: A Case Study from Sri Lanka. J Remote Sensing \& GIS 6: 206. doi: 10.4172/2469-4134.1000206

Page 5 of 7

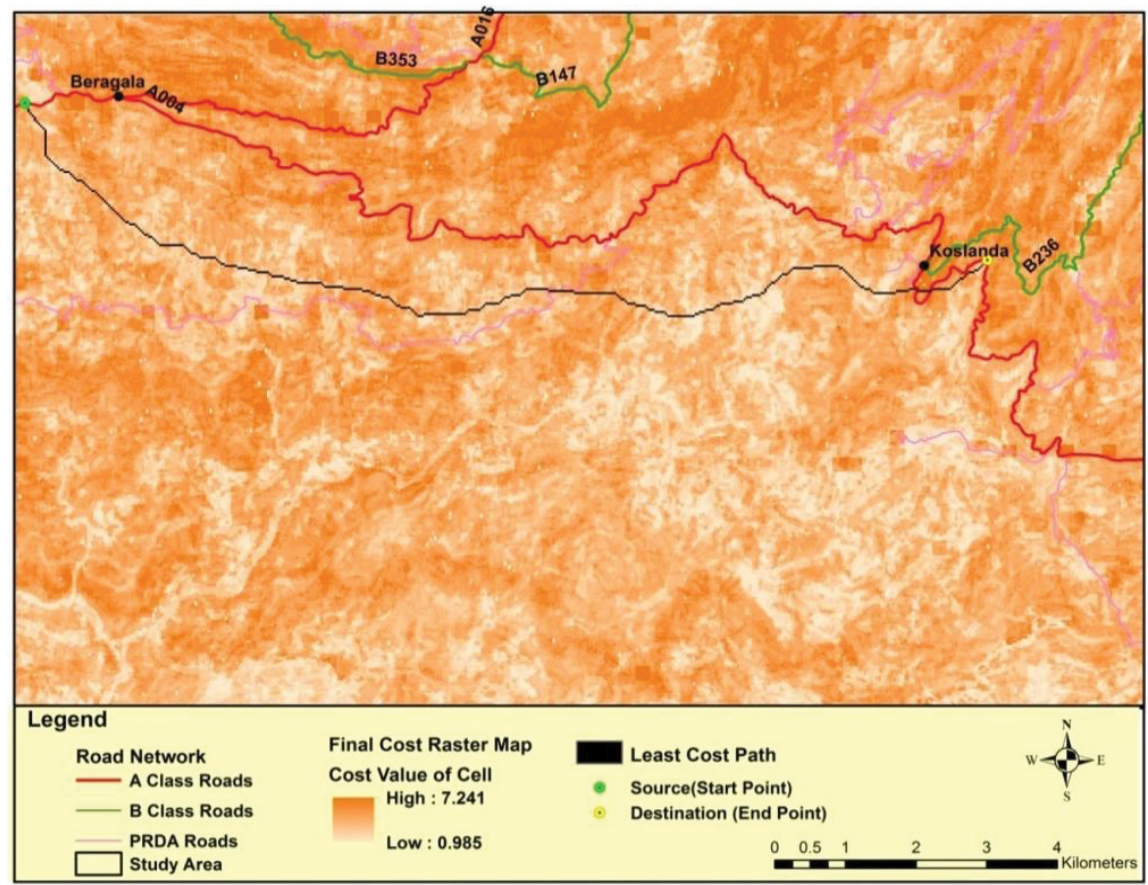

Figure 2: The map showing the least cost path.

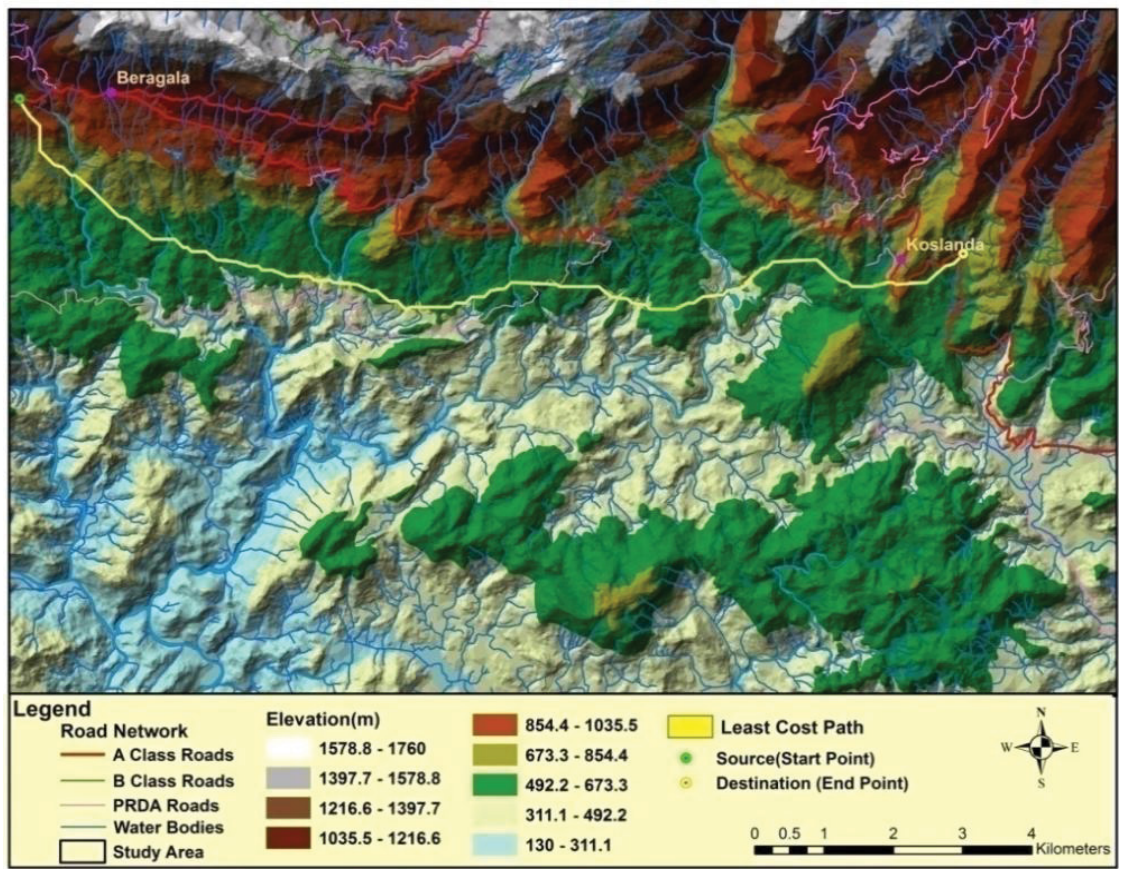

Figure 3: Least cost path with terrain

Vertical alignment: As per the Highway Design Manual, vertical alignment of the roads also depends on the terrain and the road class. Maximum gradient was defined as $8 \%$ for " $A$ " class road in a mountainous terrain. Since the selected road is "A" class road in mountain area, its maximum gradient also should be $8 \%$ or less than $8 \%$. As such, in this study, the gradient of the path has been calculated to evidence of the suitability of identified path. The gradient values of road sections are shown by below table (Table 4 ).
According to above table, $48 \%$ of identified path is good for the road construction when considering the gradient of the path. While $32 \%$ of the path is in manageable condition, only $19 \%$ of the path is not good for road construction. However, adding suitable and manageable area together clearly identified that $80 \%$ of the selected path is good for road construction. Elevation profile of the path (Figure 5) gives more visible gradient and it is easy to identify whether the selected route is suitable or not suitable for road construction. 


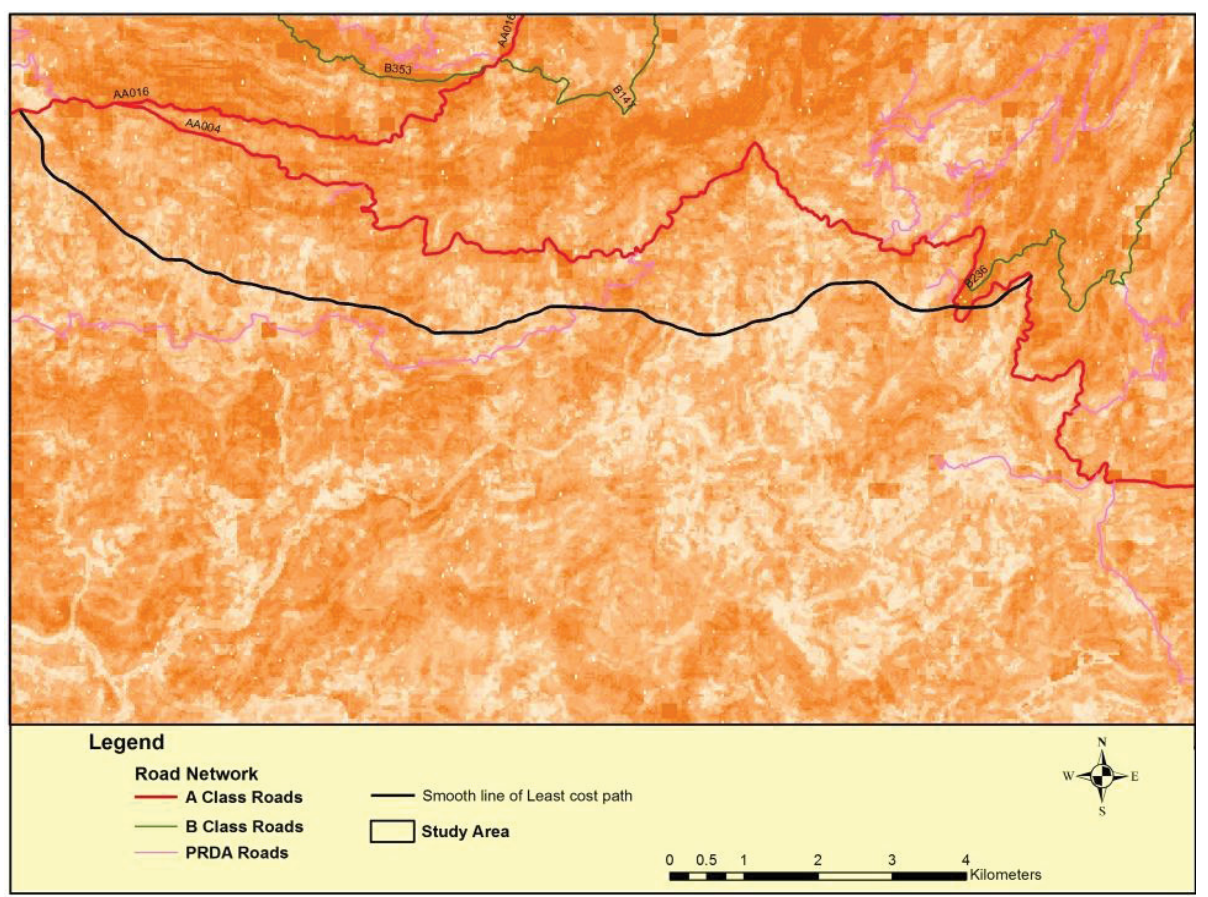

Figure 4: The Map Showing the Path with Acceptable Radius.

\begin{tabular}{|c|c|c|c|}
\hline Gradient & Length & Total Length & Percentage (\%) \\
\hline $0-6$ (Suitable) & 7414 & 15414 & 48 \\
\hline 7-12 (Manageable) & 5000 & 15414 & 32 \\
\hline$>12$ (Not Suitable) & 3000 & 15414 & 19 \\
\hline
\end{tabular}

Table 4: The Percentage Values of the Gradients of Least Cost Path.

When considering the elevation profile, with the limited number of cutting and fillings the path can be built up. According to the elevation profile of the path, starting section has gone through the steep slope area taking high gradient values. This was happened due to lack of data used for the study.

\section{Field verification}

Field verification of this study has been carried out through a field survey. When going through the path, abandoned road was identified near (180 m away from the path) the starting section. That road had been used for Tea factory. It was an asphalt paved road and now covered by bushes. Some small existing roads can be seen close to the identified path. In addition, there are some small routes close to the identified path and sometimes the route goes through the existing small roads.

According to the above information, it can be clearly stated that the necessary requirements of the road construction are satisfied with identified path. Engineers who have participated for the field verification are satisfied with this alignment. Their comments were very valuable for the verification. As mentioned earlier there could be some errors when the model is applied in the field. Thus, except the starting section, only one section of the middle of the road was identified as unsuitable area for road construction. Following figures indicate the actual situation of that location.

The section of the alignment indicating in the Figure 5 is only the section which is unsuitable area for road construction. According to this figure, mountain is crossed by the route, as well as the section of elevation profile is covered by the red circle expresses that the gradient is very high.

According to the field information, engineers' decision was to shift the alignment of the identified trace to the north in order to minimize this problem. Nevertheless, it is required to identify the reasons for the alignment to go through the mountain without going through the northern part of the mountain. Therefore, effects of the all factors have to be studied in that area. Finally, $15.414 \mathrm{~km}$ longer alternative route was identified from Beragala to Koslanda landslide area instead of the existing $17.75 \mathrm{~km}$ road.

\section{Conclusions}

SMCA was used to identify an optimum road alignment in Beragala - Koslanda area. Seven factors were identified and handling the multi geo data was a difficult task. But Spatial Multi Criteria Analysis (SMCA) is one of the best methods which can be used to weight and rank those types of factors. As such, considering cost effectiveness of road construction, pairwise matrix in SMCA was developed according to the values given by the experts. Hence, seven factors which were considered, were weighted and ranked in following order, (1) Landslide hazard zone, (2) Sensitivity area, (3) Slope, (4) Populated area, (5) Drainage order, (6) Land use and (7) Geology. Likewise, the first objective of the study was fulfilled.

It is noted that soil condition is one of the major factors to be considered in road construction, but it was not considered in this study due to lack of engineering soil properties for entire area. Soil testing is also time consuming and costly in Sri Lanka. As such this research was carried out by only using the seven factors.

Field verification of this study reveals that the proposed method can be successfully used to determine the optimum path for a landslide area. Although the identified path is the least cost path, it is not the optimum route alignment, because geometric design of the road has 


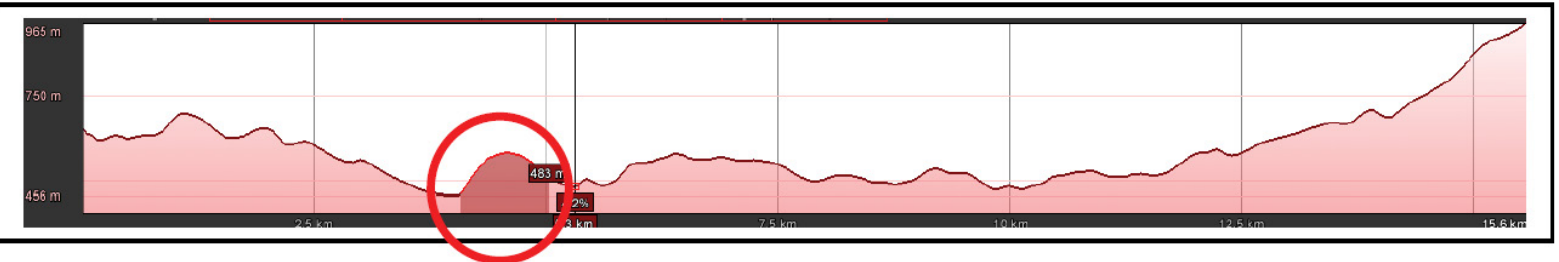

Figure 5: Showing the unsuitable location of the route on Elevation Profile.

not been incorporated when identifying the route alignment. Most important geometric features are vertical and horizontal alignments of the road. As such, geometric features of the road were incorporated to transform the least cost path into optimum route alignment.

During the field verification, one section of the identified optimum route alignment is not suitable for the road construction. That section traversed through the mountainous area. According to the decisions of the engineers who participated in the field verification that section could also be moved some extent to the northern side. Then with some landslides mitigation measures taken, road can be constructed. Otherwise a tunnel should have been built to cross the terrain.

Likewise, the optimum route alignment for the selected landslide area was identified fulfilling the third objective of the research.

Up to this level the selected road trace satisfies only landslide hazard risk and the geometric design characteristics. However, further studies should be done to ensure that the selected route alignment satisfies other engineering design characteristics such as Traffic volume, Soil types, Separate Drainage Designs for culvert and bridges and Esthetical Designs, to decide the final route trace.

Finally, most suitable method was developed for the selection of route alignment and this method can be recommended as a better way to select a route alignment. By changing the factors affecting, this can be applied not only for the landslide prone areas, but also for other areas where landslide risk is not a problem.

\section{References}

1. Castellanos AEA, Van WCJ (2007) Generation of a landslide risk index map for Cuba using spatial multi-criteria evaluation. Landslides 4: 311-325.

2. Nayana Padmani WAK (2013) Identification of optimum route alignment in landslide areas using GIS and Remote Sensing. MSc Thesis, IHRA, University of Colombo.

3. Saha AK, Arora MK, Gupta RP, Virdi ML, Csaplovics E (2004) GIS-based route planning in landslide-prone areas. International Journal of Geographical Information Science 19: 1149-1175.

4. Understanding Cost Distance Analysis (2012)

5. Geometric Design Standards of Roads (1998) Road Development Authority. 